\title{
"We NEED TO REDISCOVER \\ THE LIVING BODY": \\ GABRIEL JOSIPOVICI'S \\ METAMODERN PROJECT IN \\ GOLDBERG: VARIATIONS
}

Brno Studies in English

Volume 46, No. 2, 2020

ISSN 0524-6881 | e-ISSN 1805-0867

https://doi.org/10.5817/BSE2020-2-15

\author{
MAgDAlenA SAWA
}

\begin{abstract}
In the epilogue to the 2002 edition of The Politics of Postmodernism, Linda Hutcheon proclaims the end of postmodernism. Emerging in its place is a new "structure of feeling," conceived by Timotheus Vermeulen and Robin van den Akker as metamodernism. Characterised by an oscillating in-betweenness or a dialectical movement between conflicting positions which are neither fully affirmed nor completely negated, the cultural paradigm of metamodernism is situated between genuine commitment and ironic detachment, between hope and melancholy, empathy and apathy, unity and plurality, totality and fragmentation, purity and ambiguity. The aim of the present article is to show that Gabriel Josipovici's novel Goldberg: Variations (2002) endorses this incipient metamodern sensibility by advocating the embodied nature of the creative process. Elaborate techniques of intermediality, the ontological instability of narrative levels and extensive metafiction are employed by the author to propound a more human perspective on literature and art in general.
\end{abstract}

Key words

Metamodernism; affect; body; Gabriel Josipovici; Goldberg: Variations

\section{Introduction}

In the epilogue to the 2002 edition of The Politics of Postmodernism Linda Hutcheon admits that "[t]he postmodern moment has passed" (181). Derrida's On Hospitality (2000), Hassan's article "Beyond Postmodernism: Towards the Aesthetic of Trust" (2003) and many other contemporary commentaries clearly indicate a substantial cultural reorientation and confirm the justness of Hutcheon's observation. Exhausted by the irony, cynicism and the overall lack of stability prevailing in the postmodern perspective, twenty-first century literary and artistic circles have developed a craving for an affective and sincere relationship with the world. This incipient tendency was conceived by two young Dutch scholars, Timotheus Vermeulen and Robin van den Akker, as metamodernism. Referring to the Platonic idea of metaxy, it denotes primarily a dynamic oscillation between the postmodern and the pre-postmodern, "between a modern enthusiasm and a postmodern irony, between hope and melancholy, between naïveté and knowingness, empathy and apathy, unity and plurality, totality and fragmentation, purity and 
ambiguity" (Vermeulen and van den Akker 2010: 4-5). Apart from a strong neoromantic proclivity, metamodernism is characterised also by the conflation of modernism and postmodernism and this aspect of the metamodern attitude is not utterly new. Categorised by Monika Fludernik (2000: 227) as "a Modernist postmodernist or a postmodern Modernist," Gabriel Josipovici has been intrigued by the interplay of modernist and postmodernist tastes since the beginning of his writing career. Although he definitely rejects the postmodern attitude - "it fails to satisfy me" (Josipovici 1999: 23) - his fiction is often characterised by insouciant playfulness, extreme fragmentation and relentless inscrutability. Such is the case with Goldberg: Variations (2002), one of Josipovici's most complex texts, which in this article will be shown as responding to and endorsing metamodern sensibilities. Two main themes undertaken by Josipovici in his novel were identified by Werner Wolf (2003: 302) as the "creative capacity" and an emotional relationship between two human beings. While the former is used to explore the problems of reading, writing, authority, tradition, craftsmanship and experimentation - all of which have preoccupied Josipovici in his major critical works - the latter proffers a solution. Following the example of his earlier novel, Moo Pak (1994), in which the anguished process of creation is explained in terms of friendship, Josipovici speaks in Goldberg: Variations through love, affectivity and the body.

\section{Goldberg: Variations: genesis and structure}

Goldberg: Variations takes its origin from Josipovici's short story "Goldberg," published as an independent piece in The London Magazine in 1989 and incorporated later into the novel as its opening chapter. Based on an anecdote, the narrative is itself a source of an anecdotal reminiscence fully recounted by Josipovici in his interview with Victoria Best. As the author explains, he took inspiration for his story from Johann Nikolaus Forkel's account of how Bach's famed Goldberg Variationen came to be composed. The anecdote tells of Count Keyserling, a Leibnitz nobleman, who suffered from insomnia. In order to elicit slumber, he asked his court musician, Johann Gottlieb Goldberg (a pupil of Bach's), to play to him during sleepless nights. The music on this peculiar occasion was provided by Goldberg's master in the form of Clavierübungen: "keyboard exercises." Josipovici's "jeu d'esprit" (Best 2015), in which the German setting is replaced by eighteenthcentury England and musical performance supplanted by night reading sessions, is the story of Mr. Goldberg, a Jewish novelist, summoned by a country gentleman, Tobias Westfield, to read to him through wakeful hours. The task assigned to Goldberg - he is expected to read at night what he has written during the day - proves an enormous challenge and produces writer's block. The scheme Goldberg devises to overcome his creative impotence involves writing a letter to his wife in which to relay his misery. As the text nears the end it transpires that the story is the letter as it is written or read to the restless Mr. Westfield.

Once brought to completion, Josipovici's story was sent to Judith Weir, a contemporary composer who shared the author's admiration for Bach's musical genius. Her favourable opinion as well as unanticipated request for the remaining 
twenty-nine variations stalked Josipovici's creative imagination for the next few years. He reminisces: "I struggled with the project, periodically growing sick of it and turning to other things, yet always coming back to it. I couldn't get it off the ground and I couldn't quite let it go. I cursed Judith Weir" (Best 2015). The fact that no other book engaged him for so long (Best 2015) points to the enormous amount of intellectual and emotional ${ }^{1}$ effort Josipovici invested in the novel and accounts for the high degree of complexity he eventually achieved in this verbal imitation of Bach's polyphonic masterpiece. The initial story is followed by twenty-nine miscellaneous revisions of the original narrative which present the perspectives of other members of Westfield's family, treat of his friendship, report on Goldberg's private life, provide descriptions of places (the prehistoric village in Skara Brae) and art objects (a still life of a cabinet and Paul Klee's Wander-Artist), relate friendly debates on such varied subjects as the Wild Boy of Aveyron or the deceitful nature of Odysseus, and embrace a mise en abyme of the novel's structure. There are indeed many voices heard in this composition and they adopt a variety of forms and genres, from traditional omniscient representation to first-person narration, epistolary chapters, long conversational pieces, excerpts from historical books and ekphrastic descriptions. What seems to be "an exercise in literary writing" is further complicated by the appearance in chapter fourteen of Gerald, a contemporary novelist, working on a new book while on a tour of European museums. Subsequent sections reveal him to be the source of all that was previously written (the story of Goldberg and Westfield) before his mastery of the text is further subjected to the control of yet another author whose reflections upon the writing process bring to mind Josipovici himself, contemplating the difficulties involved in the creation of the very book we are reading.

Various aspects of the correlation between Goldberg: Variations and Bach's musical composition were thoroughly studied by Werner Wolf in his article "The Role of Music in Gabriel Josipovici's Goldberg: Variations" while the interconnectedness of diegetic levels in Josipovici's heterogeneous text came under close scrutiny in Dominique Pernot's study "Metaleptic Variations." In their insightful discussions of Goldberg: Variations both Wolf and Pernot make it abundantly clear that this novel is the highest expression of Josipovici's technical virtuosity as well as a vehicle for voicing his views on literature and aesthetics to which he has adamantly adhered throughout his writing life; hence the self-reflexive presence of writers unable to progress with their works, the nonrealistic rendering of their struggle and the motif of failure engendered by the "precarious status" (Josipovici 2010: 11) of all art. While those two critics are perfectly able to justify their admiration for Goldberg: Variations by pointing to its elaborate interart correspondence and structural complexity, Victoria Best, a writer and a perceptive critic of Josipovici's fiction, ${ }^{2}$ senses that the nature of this book's grandiosity may lie somewhere else. She initiates her conversation with the author about the novel with a vague commentary: "Let's talk about Goldberg: Variations, which strikes me as your most widely-reviewed novel to date. I also find it quite different to everything else you've written without being able to put my finger on why that should be so" (Best 2015). As I will attempt to demonstrate in this article, Best's intuition about Josipovici's book is unerring while her inability to explain the 
uniqueness of Goldberg: Variations stems from the fact that scant critical attention has hitherto been paid to that aspect of the book which makes it so unique. Both Wolf and Pernot allude to it in their studies when they speak of "the allegorical embodiment [...] of creative capacity" (Wolf 2003: 304) or claim that "The writer is not dead yet in spite of many ominous prophecies by eminent critics" (Pernot 2014, par. 36). Neither of them is ready to admit, however, that the problem of the embodied nature of the creative process informs the whole of Goldberg: Variations, combining thus the individual parts of the book's bipartite theme, identified by Wolf as the "creative capacity" and an affective relationship between two human beings, into one.

Josipovici's idea of aligning literary production (and reception) with the body in Goldberg: Variations can be looked upon from three different angles. First, the book is a literary contribution to the interdisciplinary discussion on the theory of embodied cognition (or the largely overlapping theory of affect) based on the premise that "consciousness is not simply something that happens within our brains, but rather something that we $d o$ through our living bodies, and our lived bodily engagement with the world" (Maiese 2011: 1). This pronouncement comes as an echo of Josipovici's own commentary: "For we are embodied, and it is our bodies which give us common access to the physical world; in other words we are participators, not spectators, and it is through embodiment that we participate." Not only in Touch, from which the above quotation comes (Josipovici 1996: 6), but also in other publications does Josipovici evince keen interest in the role of the body in human perception of the world, specifically in Writing and the Body and On Trust: Art and the Temptation of Suspicion. Goldberg: Variations seems to provide a good opportunity for these interests to resurface in fiction. Second, concerned primarily with the problem of the role of the body in artistic creation, Josipovici's novel voices its concerns by way of metamodern insistence on affectivity. Not only, however, is the affective turn in general "resonant with broader strains in what has been dubbed 'metamodernism' as a 'structure of feeling' that oscillates between modernist and postmodern relativism" (Brinkema 2014: xii), but it also manifests itself in the metamodern interest in individual emotional experience, anchored in the present, embodied and situated. The vagaries of human love relations, notably rendered in Josipovici's novel in the form of letters, are meant to induce the understanding of both reading and writing in terms of affective interactions. Third, considering literature in the context of the body must necessarily lead to the person of the author and their bodily presence behind the text. Rather than a trick in postmodern stylistics, the implied presence of the author in his own work becomes in Goldberg: Variations a guarantee of the authenticity of the text as well as Josipovici's minimalist attempt at restoring the human aspect of literature.

\section{Goldberg: Variations and the body}

As early as 1981 and soon after publishing his most influential critical studies, The World and the Book (1971) and The Lessons of Modernism (1977), Josipovici 
made the problem of the relation between literature and the body the central focus of a series of lectures he delivered at University College in London, which were later published in an almost unchanged form as Writing and the Body (1982). Despite the fact that since the 1990s the study of affect and embodied cognition has been a major growth area in such disciplines as psychology, psychoanalysis, neurobiology, social studies, philosophy and the humanities, and produced a number of engrossing studies, such as Antonio Damasio's The Feeling of What Happens (2000), Sondra Pearl's Felt Sense: Writing with the Body and Mark Johnson's The Meaning of the Body: Aesthetics of Human Understanding (2008), ${ }^{3}$ providing a complete explanation of Josipovici's eponymous correlation remains an impossible task. Josipovici seems to possess full awareness of the complexity and inconclusiveness of his venture as he opens his study with the following observation: "Our bodies are, in a sense, more familiar to us than our closest friends; and yet they are - and will remain - mysterious and unfamiliar until we part from them. They are all we have - yet can we really be said to have them?" (1982: 1). Without referring to any specialised discipline but drawing on "a little imagination, a little attention" (Josipovici 1982: 130), he points instead to the compound nature of writing, which lies at the crossroads of the mental and the physical, the orders of nature and culture. He further likens the production of literature to laughing or screaming, since it is rooted in similar biological processes. At the same time, he accentuates literature's belonging to the cultural system of representation. On the one hand, the body/mind interdependence is so trivial that it makes the process of writing, the great teleological process of meaning production, "uncertain, insecure, liable to come to a stop at any moment as the result of cramp, boredom, despair, or any one of hundred unforeseen circumstances" (Josipovici 1982: 1). On the other hand, often compared to "something almost physical, like the need to breathe" (Josipovici 1999: 1), writing must follow a bodily rhythm, or, to use the phrase Josipovici adopts from two neurologists, Alexander Luria and Olivier Sacks, "kinetic melody." Normally we do not concentrate on each step we take, still less on the proprioceptive balance it entails. Faced with patients who displayed very high levels of self-awareness, Sacks realised the need to give them enough confidence in their own abilities so as to make them ignore the conscious control of the mind and let the body discover its own rhythm; hence the term "kinetic melody," used to denote the healthy balance between conscious effort and natural movement. As Josipovici (1999: 273) observes, Sacks's experience with the disabled can be illuminating of the creative process itself and help us understand that "in the rather different area of artistic creation the discovery of each artist of kinetic melody is the way to overcome the debilitating effects of the disappearance of craft traditions and the rise of suspicion." The problem of body/mind coordination, which is supposed to warrant writers sureness of hand and protect them from the authority crisis vexing the modern mind, is discussed in Goldberg: Variations obliquely through the motif of insomnia.

In Goldberg: Variations the eponymous Jewish writer comes to the rescue of Mr. Westfield, a philosopher afflicted with sleeplessness, soon to be overwhelmed by a similar problem. Both Westfield in his inability to sleep and Goldberg in his 
inability to write appear as victims of modernity. According to Josipovici's bold statement, modernism, as the critical undertow of modernity in the sphere of art, originated in reaction to the sixteenth-century "disenchantment of the world". Inasmuch as Max Weber's phrase designates a transition from "an era of superstition to our modern era of common sense and scientific understanding, from the darkness of the Middle Ages to the light of the Enlightenment" (Josipovici 2010: 12), it emphasises also a substantial difference between "'the age of cult' and the 'age of individual'" (Josipovici 2010: 17) as well as the growing rift between the world of trust, receding into the past, and the world of suspicion, becoming actuality. Defined as "the coming into awareness by art of its precarious status and responsibilities" (Josipovici 2010: 11), modernism is characterised by self-reflexive commentary on the nature of artistic creation. This self-reflexivity in art can be viewed as symptomatic of what became the curse of the modern man - his pervasive questioning of his own position in the world: his relation to God, history and tradition. With Descartes' succinct delineation of the essence of the modern man - "I think therefore I am" - modernity began also with the questioning of the body in favour of the thinking mind. A closer inspection of Descartes' dictum clearly indicates that modernity takes its roots from "metacognitive objectification of cognition" (Scrivner 2014: 49). This state of heightened self-awareness as well as the programmatic disregard of the body make modernity akin to insomnia. Engendered by attentive objectification and examination of the self, sleeplessness "thrives at the problematic intersections of the psychological and the physiological" (Scrivner 2014: 21). All this makes insomnia a typically modern phenomenon: "insomnia in reference to chronic sleeplessness has always been modern" (Scrivner 2015: 16). Albrecht Dürer's engraving Melancolia I (1514), studied by Josipovici as an early instance of modernist self-reflexivity in art, aptly communicates this interdependence. Melancholia - the modern man/artist - is sleepless and inert, "her considerable energy [...] paralysed not by sleep but by thought. She is reduced to inactivity and despair by the awareness of the insurmountable barrier separating her from the realm of Truth" (Josipovici 2010: 25-26).

In a quite similar way, Westfield is a compulsive thinker, afraid to stop philosophising for fear that the world might disappear:

He began to get the feeling that it was up to him to hold the world together. This was a task that required his utmost concentration and all his will-power at every moment of the day and night. If he relaxed for even an instant the world threatened to fly apart into myriad of fragments or else simply to fizzle out. (15)

This is an instance of Descartes' famous sentence being taken literally and thus parodied, especially since excessive thinking eventually exhausts the body and brings Westfield to the brink of death. His insomnia develops as a consequence of the growing feeling of self-consciousness and metacognitive monitoring of whatever was happening to him in life: "The way he put it to himself was that everything had developed an echo" (14). The root of the problem should be sought in his early years. The moment he decided to adhere to his father's ideal of com- 
posure precipitated his future misery and "marked the end of his childhood and the start of his adult life" (Josipovici 2002: 66).

Part ten of Goldberg: Variations, which describes the conflict between Westfield's mother and father about their son's upbringing as well as the boy's changing attitude towards his parents' contrasting methods, is identified by Wolf (2003: 314, note 15) as "[t]he most difficult chapter in terms of recognising a relationship to the theme of creative capacity." If, however, we construe Westfield's rejection of his mother's emotional attitude in favour of his father's rationality and self-control as symbolising his repudiation of the body as well as a foreshadowing of his ongoing intellectual alienation and sleeplessness, the connection of this problematic chapter to the rest of the novel will be immediately re-established. Thus understood, chapter ten becomes a significant contribution to the theme of the embodied nature of the creative process or, in a broader sense, the relation between the mind and the body. Concomitantly, such an approach shows that many other narratives in the book, about which critics prefer to stay reticent, are apposite and valuable. Such is the case with chapter six in which Westfield reproaches his elder son for being "seen in a most compromising situation" (45) with one of his woman friends. Finding Westfield immune to bodily attraction, Mrs. Simmons redirects her attention at Gerald whereby the estrangement of father and son, the man of "altogether superior intellect and sensibility" (39) and his senseless bodily counterpart - "The same proud holding of his head, the same blue eyes, the same set mouth" (83) - deepens. ${ }^{4}$ Similarly, Westfield's absorption in philosophical matters causes his alienation from his wife, who describes herself in chapter twelve as "reduced to being a single point of anger and despair" (86). While Isaac Sinclair, the protagonist of chapter thirteen whose emotional sensitivity overrules reason and leads him to madness, appears to be Westfield's counterpart, Maria, Westfield's first wife, shows clear affinity with her husband when she pays for her Venetian fantasies with her own life. The problem of the body/ mind conflict permeating and defining Westfield's family relations is considered in a broader context in chapter five, which deals with the prehistoric village of Skara Brae in the North of Scotland. This instance of human Neolithic settlement was engulfed in sand during one of the "fierce south-westerly gales" (36) and in no time ceased to exist. When the same natural force uncovered the place in 1851, it emerged as a battlefield - "One woman in her haste to squeeze through the narrow door of her home [...] broke her necklace and left a string of beads behind as she scampered up the passage" (36) - in which nature and civilisation strove for dominion. Goldberg's conversation with Hammond about a wild boy found in 1797 in the forests of Southern France pertains to the same problem of civilisation, memory and language being tenuously dependent on the body. In a more optimistic yet rather surrealistic manner, chapter seven speaks of a telepathic communication between twin brothers: "this unnatural seepage of the mind and the body of the one into the other" (48).

When asked to give reasons for his creative impasse, Goldberg provides the following explanation: 
But, alas, our own age is grown altogether less inventive and more melancholic, and few can now find it in their hearts 'to take a point at pleasure and wrest and turn it as he list, making either much or little of it, according as shall seem best in his own conceit', as an ancient writer on these matters put it. For what we list has grown obscure and difficult to define. (10)

Uncertain of his purpose, the modern writer/artist turns upon himself and becomes paralysed by the number of decisions involved in the creative process, for creation appears as a purely arbitrary and private enterprise. Accordingly, in chapter nine creative thinking is perceived as a butterfly whose erratic flight in one's head precludes sleeping and reasoning. Not only does writing in modern times inevitably engender sleeplessness, but it becomes synonymous with it: "insomnia has remained an unambiguously lonely, solitary experience. It goes on in the privacy of our own individual consciousness" (Scrivner 2014: 181). Sleeplessness befalls all the authors in Josipovici's novel, with the exception of Goldberg, The Lord of Time, as he is called by Westfield. Their struggle culminates in chapter twenty-nine, a surreal dream scene ${ }^{4}$ belonging to any of the three leading novelists. The ambiance of merriment and fulfilment predominating in this bizarre vision of festivity is a sign that the feeling of suspicion is yielding to trust, "trust in the material, trust in our abilities, trust in the act of making itself" (Josipovici 1999: 3). Sleep comes as the acceptance of the natural rhythm of time and the body, and so does creation.

\section{Goldberg: Variations and affect}

In their article "Notes on Metamodernism" (2010) as well as in their subsequent publication (with Alison Gibbons as the third editor) Metamodernism: Historicity, Affect, and Depth After Postmodernism (2017), Timotheus Vermeulen and Robin van den Akker respond to Linda Hutcheon's incentive:

The postmodern moment has passed, even if its discursive strategies and its ideological critique continue to live on-as do those of modernism-in our contemporary twenty-first-century world. Literary historical categories like modernism and postmodernism are, after all, only heuristic labels that we create in our attempts to chart cultural changes and continuities. Postpostmodernism needs a new label of its own, and I conclude, therefore, with this challenge to readers to find it-and name it for the twenty-first century. (2002: 181)

Dissatisfied with the panoply of terms, such as digimodernism, pseudomodernism, automodernism and altermodernism, and the problems of the contemporary world they profess to address, Vermeulen and van den Akker propose "metamodernism" as the most accurate name for the dominating sensitivities of the turn of the century. Defining their goal as "mapping, transcoding and situating contemporary aesthetics and culture by way of the arts" (van den Akker et al. 
2017: xi), they point to new tendencies in art production which have emerged in the last decades and a new brand of artists who can "see the distinction between earnestness and detachment as artificial; they grasp that they can be ironic and sincere at the same time, and they are making art from this compound-complex state of mind" (Saltz 2010). What makes metamodernism capable of capturing this idea of commingling polarities is its etymological source. The prefix "meta," as Vermeulen and van den Akker explain, refers to the Platonic idea of metaxy, used in Symposium to describe a sense of in-betweenness in the experience of the demigods of ancient Greece. In consequence, metamodernism is characterised by an oscillating in-betweenness or a dialectical movement between conflicting positions which are neither fully affirmed nor completely negated; it is situated "between a modern enthusiasm and a postmodern irony, between hope and melancholy, between naïveté and knowingness, empathy and apathy, unity and plurality, totality and fragmentation, purity and ambiguity" (Vermeulen and van den Akker 2010: 4-5), and defined broadly as "a structure of feeling that emerges from, and reacts to, the postmodern as much as [...] a cultural logic that corresponds to today's stage of global capitalism" (van den Akker and Vermeulen 2017: 5). As the aforementioned definition clearly indicates, in their attempt to define contemporary cultural situation in terms of metamodernism, Vermeulen and van den Akker are indebted to Frederic Jameson's seminal study Postmodernism, or, the Cultural Logic of Late Capitalism. Inspired by Jameson's "senses of the end of this or that" (1991: 1), they draw our attention to the weakening of certain postmodern tendencies, such as "pop art and deconstructive conceptual art [...]; punk, new wave and grunge's cynicism in popular music; disaffected minimalism in cinema; spectacular formalism in architecture; metafictional irony in literature, as well as the whole emphasis on a dehumanising cyberspace in science fictions of all kinds" (van den Akker and Vermeulen 2017: 2). In their place new trends emerge - the New Romanticism in the arts or the New Weird in music - whose products partake of postmodern stylistic and formal tactics which, however, are employed for different purposes. Also worth mentioning is the literary trend known as the "New Sincerity" ensuing from critical and fictional writings by David Foster Wallace. Van den Akker, Vermeulen and Gibbons, as well the scholars invited to contribute to the discussion on metamodernism, often stress the importance of Wallace's reflections for the reconfiguration of the postmodern attitude. Already in his 1993 article "E Unibus Pluram: Television and U.S. Fiction" he launched a critique of postmodern ironic detachment, advocating instead literature imbued with earnestness and hope. The theory was put into practice in Infinite Jest where the tenets of postmodernism are exposed and interrogated in a way which clearly anticipates the metamodern formula: "Wallace uses irony to show what irony has been hiding. He does not merely join cynicism and naïveté: rather, he employs cynicism [...] to recover a learned form of heartfelt naïveté" (Boswell 2003: 17). In his more contemporary project, named "postirony" and discussed in Metamodernism as part of the broad metamodern perspective, Lee Konstantinou (2017: 88) continues Wallace's thought by articulating similar concerns: "Van den Akker and Vermeulen's analysis makes perspicuous the hesitancy, uncertainty and confusion with which postironists have undertaken more and less ambitious efforts to move beyond postmodern irony 
in search of firmer emotional, artistic and political ground." Although markedly different in terms of style, method and theme, such writers as Zadie Smith, Jonathan Lethem, Ian MacEwan, Ben Lerner, Ruth Ozeki and Ali Smith, to name but a few, repeatedly employ the postironic mode in their fiction.

Unlike postmodernism, characterised by ironic distance, prevalent scepticism and, in Jameson's words, the "waning of affect" (1991: 10), metamodernism places affective engagement in the centre of its attention. What needs to be immediately dissipated, however, is the confusion around the term "affect" which makes the relation between affect and postmodernism (and thus also between affect and metamodernism) somewhat problematic. Two basic approaches to affect can be identified: ontological and situational (Gibbons 2017a). The first is much influenced by Gilles Deleuze and championed by his translator and critic, Brian Massumi (2002: 28), who makes a clear distinction between affect - a pre-personal, pre-conscious and pre-cognitive intensity - and emotion, defined as

a subjective content, the sociolinguistic fixing of the quality of an experience which is from that point onward defined as personal. Emotion is qualified intensity, the conventional, consensual point of insertion of intensity into semantically and semiotically formed progressions, into narrativizable action-reaction circuits, into function and meaning.

When considered in relation to a thinking, feeling human subject, affect is often understood as situational and tantamount to Massumi's explication of an emotion. Such is the case with Jameson's discussion of Vincent Van Gogh's modernist painting A Pair of Boots (1887) and Andy Warhol's postmodernist image Diamond Dust Shoes (1980). While the former encourages an emotional reaction of sympathy towards the presumed owner of the worn pair of peasant shoes, the latter, commodified and superficial, "does not really speak to us at all" (Jameson 1991: 8). It is in the context of this comparative analysis in which hermeneutic emotion and postmodern emotional fallacy are juxtaposed that the popular "waning of affect" diagnosis emerges. However, at another point in his extended study of the postmodern condition Jameson uses the term "affect" in a different, ontological sense when referring to "euphoria, a high, an intoxicatory or hallucinogenic intensity" (1991: 28) as "free-floating" and "impersonal" (1991: 16). Thus understood, affect, as Massumi (2002: 27) rightly notes, was far from waning in the postmodern world. In an attempt to marshal the discussion on affect in relation to both postmodernism and metamodernism, Gibbons (2017a: 85) makes the following observation:

In the contemporary [art] [...] we can perhaps speak once more of a hermeneutics of the self, a will and ability to process intensities so that we can articulate meaningful emotional reactions or cognitive responses to today's social situation in which another affective modality has substituted yesterday's fragmented and fragmenting euphoria.

Concurrent with metamodernism, the contemporary revival of affect has its corollary in the possibility of replacing the postmodern "flatness and depthlessness" 
(Jameson 1991: 9) with the search for a situated subjectivity, positioned "corporeally in the world, including in relation to others" (Gibbons 2017b: 120).

In Goldberg: Variations the illusion of depth is created by means of the overlapping layers of narration, which produce the effect of

[a] vertiginous descent into narrative depths: one feels that the downward movement could become infinite - an infinite regress - without ever coinciding with the concrete writer, Josipovici himself, with the unending interposition of a new persona between his real self and the projected one, playing his own variation, his idiosyncratic fugue for three voices. (Pernot 2014, par. 29)

Despite the constant deferral of the author's presence, Josipovici's novel issues an invitation to perceive literature in terms of an affective interpersonal relationship. In order to recognise this tacit incentive, a closer look at the novel's structure is required.

Wolf (2003: 300) argues that "whoever expects the novel as a whole to imitate the form of theme and variations, in particular Bach's Goldberg Variationen, and whoever consequently believes that Josipovici's text is to this extent 'musicalized fiction' is quite soon confronted with a major problem [...]". He goes on to explain that unlike Bach's opus which consists of an "Aria" (the theme), 30 variations and a final "Aria da capo" (a repetition of the theme in its original form), Goldberg: Variations contains only 30 chapters. The question arises then: what has been omitted from the original composition? Although the correspondence between individual chapters and their musical counterparts is at times difficult to establish, Wolf (2003: 300) comes to the conclusion that Josipovici's novel "is a series of variations without the traditional initial section (and concluding repetition) in which the theme appears in its simplest and clearest form." As it is indeed difficult to imagine Josipovici, or any other writer, formulating the theme "in its simplest and clearest form" at the onset of his work and then repeating it again in the form of a conclusion, Wolf's assertion seems undeniable. However, the impression that all the other stories in Goldberg: Variations are predicated upon chapter one is also hard to avoid. It is there that Westfield's words specifying the aim of the book can be found: "We need to rediscover the living body" (Josipovici 2002: 5). As a story of its own gestation (Wolf 2003), the opening chapter aims to do what it says. Therefore, Westfield's command is immediately executed through the formal qualities of the text. Significantly, the chapter which opens the whole series of variations is written in the form of a letter, the most embodied piece of writing into which the physical existence of the author and that of the addressee are inherently inscribed. Letter writing is one of the earliest forms of human literary practice, aiming at communication, assuming various forms and serving different functions (royal decrees, military orders, love letters). The quality common to all types of letters is that they signify in the absence of the author, becoming thus indicative of his/her distant existence. As a substitute for the absent body letters are "touched, held, smelled; they are stored away, hidden and destroyed" (Barton and Hall 1999: 8). In no other type of writing is the 
materiality of the text so cherished, so close to the body which produced it. What thus inevitably inheres in letter-writing is "a contiguity of inscribing hand to letter sheet, which receives and bears a text whereby one soul speaks to another by virtue of the artifact's eventual contiguity with the addressee's body and (hence) soul" (Decker 1998: 15). Aware of this fact, Goldberg concludes his letter to the king in chapter sixteen with the following formula: "To His Royal Majesty, this poor gift is offered in lieu of his body by your most humble servant, Samuel Goldberg" (Josipovici 2002: 125). Placing an epistle at the beginning of what is written in the form of "exercises in literary writing" (Bach's Clavierübungen) makes it a prototypical text upon which our understanding of literature (and art) production - as an "interplay through the text between the author's intentional artifice and the reader's attentional construction and reconstruction of meaning" (Harker 1988: 13) or, more succinctly, as "an act of communication with an ongoing interpersonal valency" (Sell 2000: 29) - should be modelled.

Both Wolf and Pernot stress the importance of different chapters in Goldberg: Variations as pivotal for their lines of analysis. Wolf (2003: 301) opts for chapter sixteen "with its massive mise en abyme of the variation form" whereas Pernot (2014, par. 30) selects part twenty-six which due to "the general crisis and selfquestioning of the represented world constitutes the heart of the novel." The choice of the embodied nature of the creative process for the leading theme of Goldberg: Variations confers special power on chapter fifteen, in which Goldberg's wife, in the form of a written conversation with her husband, intuits about the nature of writing. She begins by stating matter-of-factly: "When you are absent I take to my notebook. It is the only way I know of being with you" (103). What follows is a beautiful series of reflections on the mystery of writing as a form of reaching out towards the other person:

But why is it not sufficient to sit in my chair and imagine myself hugging you? After all, when I write here in my notebook you are no more present than if I closed my eyes and thought of you. Indeed, less so perhaps, since if I close my eyes I can see you, whereas when I write I certainly do not. But when I hug you I do not see you, I feel you. And that is what seems to happen with writing. (105)

As follows from the many instances of letter communication in Goldberg: Variations, writing is always affectively charged, anchored in a particular place, time and body. And so is any form of art creation as well as its reception. Even the mysterious still life, presented in chapter eleven in the form of a meticulous and dispassionate ekphrastic description (and making its brief appearance also in chapters two and fourteen), originates in Westfield's fear, while it connotes pain for Gerald as it is in front of this painting in the Unterlinden Museum that his wife, Edith, in a strange moment of epiphany, decides to leave him.

Chapter one and many other textual variations which take the form of a letter or a series of letters alert us to the fact that letter writing gave rise to the development of different genres, including the novel. Contrary to the common tendency among literary historians to consider the narrative of action as the precursor of 
the novel (Cervantes, Defoe), Janet Gurkin Altman (1982: 5) maintains that scholars "who investigate the origins and fortunes of the letter genre necessarily contribute to our general understanding of the rise of the novel itself, since epistolary narrative is primarily a product of that formative era in which the novel staked out its claim to status as a major genre." Originating from this pregnant remark, Altman's argument evolves to regard the epistolary novel "as a metaphor for all narrative, even all literature, a mise-en-abime of the problems of communication from writer to reader" (MacArthur 1990: 14). This critical evaluation to which Josipovici, a severe critic of the traditional nineteenth-century canon of realism, would probably subscribe may provide an explanation for the author's frequent resort to the letter form in Goldberg: Variations. What makes the epistolary novel particularly germane to this study is the fact that "[t]he letter writing characters $[\ldots]$ cannot make insinuations about the future and they cannot explain the significance of the present events in relation to a large whole" (MacArthur 1990: 8 ), which in turn makes them unable "to suggest inexorable progress towards a significant and predetermined end" (MacArthur 1990: 9). Rooted in the present and free from the expectations of plot and closure, the epistolary novel conforms to the rules of formal realism in which life is not perceived as a story. This is the lesson Ballantyne tries to teach Westfield:

The trouble with you [...] is that you have always had a hunger for stories. The life cut tragically short is a story, and the life satisfactorily completed is a story, as is the life of the insomniac who is lulled to sleep by sweet music. You have never been willing to face to the fact that life is not a story, that the poets and novelists and playwrights have been lying to us since the dawn of creation and pandering to our fears and desires. (128)

One of the significant conclusions which can be drawn from Goldberg: Variations is that life, as much as artistic creation, is hindered by the struggle for meaning, "the will to truth, to interpretation, [which] is not a given, but is an aspect of our culture, a culture forged in the sixteenth and seventeenth century" (Josipovici 1982: 129). What they both require is the appreciation of the process, the here and now, or, in other words, the favouring of metonymy over metaphor, continuation over closure. ${ }^{5}$ If even this sort of art still involves lying, it is because artists, like the cunning Odysseus in chapter eight, must "trust in time as [they] advance by a process of trial and error, intuition and correction, responsive to the world at every step, confident that [their] error and confusion will arrive at something true [...]" (Josipovici 1999: 271).

\section{Goldberg: Variations and the author}

What Ronald Curran recognises as the chief motivation behind Writing and the Body can be also seen as underlying Goldberg: Variations. It is thus possible to consider both works as a response to the school of post-structuralist criticism, "the kind which denies the bodies of readers and writers alike" (Curran 1983: 693). It 
is true that Barthes's ideas expressed in "The Death of the Author" may not be congruent with what Josipovici/Goldberg: Variations seems to proffer, but what reads like a reconsideration of Barthes's radical stance in Sade, Fourier, Loyola comes close to capturing the main concern of the novel:

The author who leaves his text and comes into our life has no unity; he is a mere plural of 'charms', the site of a few tenuous details, yet the source of vivid novelistic glimmerings, a discontinuous chant of amiabilities, in which we nevertheless read death more certainly than in the epic of a fate; he is not a (civil, moral) person, he is a body. (1989: 8)

Analogously, Paul Klee's poster-painting Wander-Artist, referred to in chapter twenty-five and twenty-seven, encapsulates, or literally embodies, the main theme of Josipovici's book. As the title of Klee's work as well as the schematic image of a human figure, walking and gesticulating, may suggest, Wander-Artist is a minimalist version of a self-portrait, just as Josipovici's novel can be viewed as a form of autofiction. This simplistic self-image came into being in a period of intense creativity which took place immediately before the artist's death in 1940. Four years earlier Klee had been diagnosed with scleroderma, a cruel and painful disease as a result of which the body becomes disfigured and the face deprived of personal traits. Like most of the works created in the last years of his life, this one can be viewed as communicating the artist's concern with his own body as well as his preoccupation with the theme of death and passing. It is difficult to decide if the black fragile figure of the artist competes against the red content of the frames or whether the fiery background is employed only to alert us to the faint presence of the artist. However withdrawn and depersonalised, the artist becomes immortalised in this little piece of art which expresses Klee's (and probably any artist's) wish "to suspend the flux of time and thereby experience eternity" (Dreifuss-Kattan 2016: 47). Placed in the context of Josipovici's novel, Wander-Artist can be further construed as the realisation of Westfield's dream of seeing "the contours, free of the content" (160), of contemplating a work of art, which, stripped of all hermeneutic clues, leads straight to its source. The author whose presence Josipovici and Klee signal in their works is not a civil, moral person, as Barthes put it, "not the one identified by our institutions (history and courses in literature, philosophy, church discourse); he is not even the biographical hero" (1989: 8), whom my interest in anecdotes might have too hastily evoked. He is a distant presence, merely a body, just enough to confront the "panintertextuality and panfictionality" (Wolf 2003: 309) of today's world.

As the book progresses, it approaches the condition of music and Klee's painting by becoming abstract, as well as surreal and mystic. Chapter twenty-six introduces yet another author (referred to simply as "he") whose emergence questions the mimetic value of Gerald's existence: "He [the new author] has tried to enliven things by inventing a present-day figure [Gerard] through which to filter the rest, but far from this giving authenticity to the work, it has only made it seem contrived and false [...]" (176). Goldberg's writerly anguish becomes thus a fictional creation of the nameless novelist upon which his own uncertainty and hesitancy is 
transposed. The part of the novel in which the mysterious other talks to the new author to remove his doubts about the writing process presents the reader with an unprecedented degree of complexity and abstraction. Simultaneously, it seeks to provide answers to a series of significant questions posed by Pernot (2014, par. 32): "Is the result of writing independent of the deep nature of its creator? Is it an anonymous and impersonal activity with not much value except as a pastime? Is writing condemned to be sterile écriture, a writing characterised by absence?" Further removed from the fictional universe, the new extradiegetic narrator, who speaks in chapter twenty-seven as Klee's wandering artist, comes to be recognised as the authorial voice. Its role is to narrate an extraordinary conversation evocative of Josipovici's definition of the process of creation. Formulated in The Lessons of Modernism as "a constant dialectic between the pain and fear occasioned by the shedding of the self and the pleasure to be had in the making of what is other than the self" (1987: xi), it clearly bears upon the title of chapter twenty-six - "Between." In keeping with the psychological conception of the dialogical self, according to which the $I$ is understood as fluctuating among different, often conflicting, positions both within the self and between the self and perceived or imagined others (Hermans and Gieser 2012: 2) as well as Wayne Booth's narratological observation that the author "makes the reader, as he makes his second self" (1983: 138), the conversation between the nameless author and the other reveals the creative process to be a constant interaction or cooperation between the self and the internalised other, the writer and the (implied) reader inherent in his own creation:

- What makes and has made these marks is not you, the other goes on, and it is not not you.

- Who is it then? he asks.

- Can you not guess? the other asks, his smile widening.

- You? (178)

This part of the dialogue brings to mind the long history of hermeneutic and narratological studies resulting in the commonly accepted idea of the narrative fiction as a six-element model involving an author, an implied author, a narrator, a narratee, an implied reader, and a real reader. Even though, as Marie-Laure Ryan (2011: 30) claims, the notion of the implied author was first introduced by Booth in 1961 as a reaction against the extreme "textualism" of New Criticism, scholars have been at pains to emphasise its distance from the real author, whose existence and intention were excluded from textual analysis. Separated by a crowd of intratextual phenomena, the real author and the real reader are never to be considered together in the study of literature. By giving physical existence, however frail and volatile, to the abstract ideal construction of the implied reader - "a textual structure anticipating the presence of a recipient" (Iser 1978: 34) - Josipovici makes this communicative void bridgeable and alludes to recent narratological revisions of the notion of the implied author (which can easily be applied to the relation between the author and the implied reader) according to which it is only as the manifestation of a real person that this figure appeals to the reader (Ryan 2011). 
The nameless author's growing awareness of the interplay between the writer and the reader (here physical and bodily), explained further in chapter twentyeight in terms of a religious offering - "I was in some sense offering my own body to release his" (182) - terminates his creative impasse so that the book can progress towards its circular, yet indubitably happy, ending:

The other does not answer but goes on smiling, so that gazing at him fills him [the nameless author] with joy, and this time the joy does not evaporate but seems to grow until it fills the entire room and the sky outside and the air, it fills the trees and envelops the birds swooping past the window, it reverberates through the room so that it is something tangible, he feels that he can reach out and touch it, and, feeling that, accepts that the other is no longer there and has dissolved into those vibrations, into trees and sky. Now the hands no longer clasp the head, the eyes no longer close in resignation. (178)

When Pernot (2014, par. 30) declares chapter twenty-six "a unique moment in all the written production of Josipovici," she does not seem to notice that its intricate conception was rehearsed in Moo Pak, preceding the publication of Goldberg: Variations by eight years. Viewed by the author as a repose from his struggle with Weir's assignment - "I turned to contemporary subjects with relief and wrote Moo Pak and then Now" (Best 2015) - this little novel prefigures what attains its full potential in Goldberg: Variations. As a contemporary fictional reworking of T. S. Eliot's "The Love Song of J. Alfred Prufrock" and thus a subtle polemic with his idea of depersonalisation, the book retains the original ambiguity of the internal/external perspective, implying that the story of the relationship between an elderly writer, Jack Toledano, and his younger companion, Damien Anderson, may be a reflection of the creative process, in which the presence of his imaginary confidante or an "optimistic conscience" (Pernot 2014, par. 33) helps Toledano overcome his writing impotence. ${ }^{6}$ While the relation between Toledano and Anderson is defined in terms of friendship, in order to explain the writer/ reader communion in Goldberg: Variations Josipovici resorts, quite predictably, to music. An apt illustration of the dynamic nature of melodic synergy in a fugue (as well as of a love relationship and marriage), the following quotation may equally well be conceived as a metaphorical description of the relation between an artist and a potential recipient of his art, in the act of contemplation or composition:

So the flight of the one from the other, which is really the flight of the solitary melody from itself, turns into the mutual respect of the one for the other, and into the physical pleasure of each in its own being, which is that of the other. The pursuer turns into the pursued and the pursued into the pursuer, and the headlong flight ceases to be a flight and becomes a dance. (133) 


\section{Conclusions}

Studying Goldberg: Variations as concerned with the relation between writing and the body or, in a more general sense, with the embodied nature of the creative process, enables full appreciation of the novel as Josipovici's utmost achievement in which the author's critical interests and aesthetic preferences coalesce into one book. Despite the strong presence of postmodern tactics, such as elaborate intermedial correspondence, ontological instability of narrative levels and extensive metafiction, Goldberg: Variations fails to comply fully with Wolf's categorisation as a postmodern novel. ${ }^{7}$ While all these strategies uncover a series of modernist artists - uncertain, faltering, too suspicious about language and tradition to proceed happily in realist fashion - they serve also to help them regain confidence in the process of creation as an embodied act of interpersonal communication, whereby the human dimension of literature is restored. Closely related to the main objective of metamodernism to transcend postmodernist detachment, the final words of Josipovici's insightful essay "Text and Voice" can aptly conclude his own efforts in Goldberg: Variations: "Let us remember that before we are critics we are readers and before we are readers we are human beings. Art is there to remind us of precisely that" (1992: 137).

\section{Notes}

1 An intense concentration on the task ensued after Josipovici's mother's death (Best).

2 See Victoria Best "The Cost of Creativity in the Work of Gabriel Josipovici," LISA 12(2) (2014).

3 Interest in the body/mind correlation has been great and systematically growing in the last decades, as evidenced by such publications as Michael Gazzaniga Nature's Mind: The Biological Roots of Thinking, Richard Schusterman Body Consciousness: A Philosophy of Mindfulness and Somaesthetics, Zdravko Radman (ed.) Knowing without Thinking, Frédérique de Vignemont and Adrian J. T. Alsmith (eds.) The Subject's Matter, David Ray Griffin Unsnarling the World-Knot: Consciousness, Freedom, and the Mind-Body Problem, Maxine Sheets-Johnstone The Corporeal Turn, and many others.

4 In his article "“[A]ll comes alive and starts to dance': The 29th Chapter of Gabriel Josipovici's Goldberg: Variations" published in LISA 12.2 (2014) Günther Jarfe carries out an interesting analysis of the surreal and overenthusiastic chapter twenty-nine, without mentioning, however, that its absurdity partakes of a dream which eventually comes to all that need it in the novel.

$5 \quad$ MacArthur explores the epistolary novel with reference to Roman Jakobson's study of metaphor and metonymy in "Two Types of Language and Two Types of Aphasic Disturbances," elaborated by Peter Brooks in Reading for the Plot: Design and Intention in Narrative. For details see Extravagant Narratives 25-34.

$6 \quad$ For details see Magdalena Sawa "'You and I' - the Fragmentation of the Writing Self and the Tradition of Modernism in T. S. Eliot's 'The Love Song of J. Alfred Prufrock' and Gabriel Josipovici's Moo Pak," Anglica Wratislaviensia 56.24 (2018), 133-145.

7 In a similar vein, reluctant to categorise Josipovici's Goldberg: Variations as postmodern literature, Theodore Ziolkowski (2010: 635) sees the novel as exploiting "motivic associations in an effort to impose order on a fragmented postmodernist mingling of episodes from past and present." 


\section{References}

van den Akker, Robin, et al. (eds.) (2017) Metamodernism: Historicity, Affect, and Depth After Postmodernism. London and New York: Rowman and Littlefield.

van den Akker, Robin and Timotheus Vermeulen (2017) Periodising the 2000's, or, the Emergence of Metamodernism. In: van den Akker, Robin et al. (eds.) Metamodernism: Historicity, Affect, and Depth After Postmodernism. London and New York: Rowman and Littlefield, 1-23.

Altman, Janet Gurkin (1982) Epistolarity: Approaches to Form. Columbus: Ohio State University Press.

Barthes, Roland (1989) Sade, Fourier, Loyola. Translated by Richard Miller. Berkeley and Los Angeles: University of California Press.

Barton, David and Nigel Hall (eds.) (1999) Letter Writing as a Social Practice. Amsterdam and Philadelphia: John Benjamins Publishing Company.

Best, Victoria (2015) The mind of the modern: An interview with Gabriel Josipovici. NC Magazine 6 (12), n. pag. Accessed on August 28, 2017. http:/ / numerocinqmagazine.com

Booth, Wayne C. (1983) The Rhetoric of Fiction. Chicago and London: The University of Chicago Press.

Boswell, Marshall (2003) Understanding David Foster Wallace. Columbia: University of South Carolina Press.

Brinkema, Eugenie (2014) The Forms of the Affects. Durham and London: Duke University Press.

Curran, Ronald (1983) Review of Writing and the Body by Gabriel Josipovici. World Literature Today 57 (4), 693.

Decker, William Merrill (1998) Epistolary Practice: Writing in America Before Telecommunication. Chapel Hill and London: The University of North Carolina Press.

Dreifuss-Kattan, Esther (2016) Art and Mourning. London and New York: Routledge.

Fludernik, Monika (2000) Echoes and Mirrorings: Gabriel Josipovici's Creative Oeuvre. Frankfurt: Peter Lang.

Gibbons, Alison (2017a) Metamodern Affect. In: van den Akker, Robin et al. (eds.) Metamodernism: Historicity, Affect, and Depth After Postmodernism. London and New York: Rowman and Littlefield, 83-86.

Gibbons, Alison (2017b) Contemporary Autofiction and Metamodern Affect. In: van den Akker, Robin et al. (eds.) Metamodernism: Historicity, Affect, and Depth After Postmodernism. London and New York: Rowman and Littlefield, 117-130.

Harker, John W. (1988) Literary Communication: The Author, the Reader, the Text. The Journal of Aesthetic Education 22 (2), 5-14.

Hermans, Hubert J. M. and Thorsten Gieser (2012) History, main tenets and core concepts of dialogical self theory. In: Hermans, Hubert J. M. and Thorsten Gieser (eds.) Handbook of Dialogical Self Theory. New York: Cambridge University Press, 1-22.

Hutcheon, Linda (2002) The Politics of Postmodernism. London and New York: Routledge. Iser, Wolfgang (1978) The Act of Reading. London and Henley: Routledge and Kegan Paul. Jameson, Fredric (1991) Postmodernism, or, the Cultural Logic of Late Capitalism. London and New York: Verso.

Josipovici, Gabriel (1982) Writing and the Body. Princeton: Princeton University Press. Josipovici, Gabriel (1987) Lessons of Modernism and Other Essays. Basingstoke: Macmillan. Josipovici, Gabriel (1992) Text and Voice. Manchester: Carcanet.

Josipovici, Gabriel (1996) Touch. New Haven and London: Yale University Press. Josipovici, Gabriel (1999) On Trust: Art and the Temptation of Suspicion. New Haven and London: Yale University Press.

Josipovici, Gabriel (2002) Goldberg: Variations. Manchester: Carcanet. 
Josipovici, Gabriel (2010) What Ever Happened to Modernism? New Haven and London: Yale University Press.

Konstantinou, Lee (2017) Four faces of postirony. In: van den Akker, Robin et al. (eds.) Metamodernism: Historicity, Affect, and Depth After Postmodernism. London and New York: Rowman and Littlefield, 87-102.

MacArthur, Elizabeth Jane (1990) Extravagant Narratives: Closure and Dynamics in the Epistolary Form. Princeton: Princeton University Press.

Maiese, Michelle (2011) Embodiment, Emotion, and Cognition. Basingstoke and New York: Palgrave Macmillan.

Massumi, Brian (2002) Parables for the Virtual. Durham and London: Durham University Press.

Pernot, Dominique (2014) Metaleptic variations. LISA 12 (2), n. pag. Accessed on May 17, 2018. http://journals.openedition.org/lisa/5843

Ryan, Marie-Laure (2011) Meaning, intent, and the implied author. Style 45 (1), 29-47.

Saltz, Jerry (2010) Sincerity and irony hug it out. New York Magazine 24 May.

Scrivner, Lee (2014) Becoming Insomniac: How Sleeplessness Alarmed Modernity. Basingstoke and New York: Palgrave Macmillan.

Sell, Roger D. (2000) Literature as Communication. Amsterdam/Philadelphia: John Benjamins Publishing Company.

Vermeluen, Timotheus and Robin van den Akker (2010) Notes on metamodernism. Journal of Aesthetics and Culture 2, 1-14.

Wolf, Werner (2003) The role of music in Gabriel Josipovici's Goldberg: Variations. Style 37 (3), 294-317.

Ziolkowski, Theodore (2010) Literary variations on Bach's Goldberg. The Modern Language Review 105 (3), 625-640.

Magdalena Sawa, Ph.D. Assistant Professor at The Department of English Literature and Culture, The John Paul II Catholic University of Lublin. She is the author of a monograph entitled Ekphrasis in Modern British Fiction - a Pro-narrative Approach (2015). She is keen to explore the problems of modern British fiction, the theory of narrative and interart relations (literature and the visual arts). Her recent scholarly interests involve affect theory and Gabriel Josipovici's writing.

Address: Magdalena Sawa, The John Paul II Catholic University of Lublin, Aleje Racławickie 14, 20-950 Lublin, Poland. [email: sawka@kul.lublin.pl] a contractual license or exception or limitation to relevant rights. 
